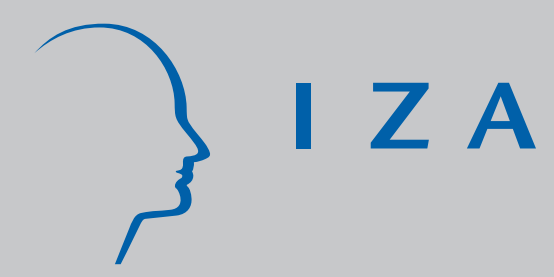

IZA DP No. 293

Gender, Comparative Advantage and Labor Market Activity in Immigrant Families

Deborah A. Cobb-Clark

Thomas F. Crossley

May 2001 


\title{
Gender, Comparative Advantage and Labor Market Activity in Immigrant Families
}

\author{
Deborah Cobb-Clark \\ SPEAR Centre, RSSS, Australian National University, Canberra \\ and IZA, Bonn
}

Thomas F. Crossley

Centre for Economic Policy Research, Australian National University, Canberra

Discussion Paper No. 293
May 2001

IZA

P.O. Box 7240

D-53072 Bonn

Germany

Tel.: $+49-228-3894-0$

Fax: +49-228-3894-210

Email: iza@iza.org

This Discussion Paper is issued within the framework of IZA's research area Mobility and Flexibility of Labor Markets. Any opinions expressed here are those of the author(s) and not those of the institute. Research disseminated by IZA may include views on policy, but the institute itself takes no institutional policy positions.

The Institute for the Study of Labor (IZA) in Bonn is a local and virtual international research center and a place of communication between science, politics and business. IZA is an independent, nonprofit limited liability company (Gesellschaft mit beschränkter Haftung) supported by the Deutsche Post AG. The center is associated with the University of Bonn and offers a stimulating research environment through its research networks, research support, and visitors and doctoral programs. IZA engages in (i) original and internationally competitive research in all fields of labor economics, (ii) development of policy concepts, and (iii) dissemination of research results and concepts to the interested public. The current research program deals with (1) mobility and flexibility of labor markets, (2) internationalization of labor markets and European integration, (3) the welfare state and labor markets, (4) labor markets in transition, (5) the future of work, (6) project evaluation and (7) general labor economics.

IZA Discussion Papers often represent preliminary work and are circulated to encourage discussion. Citation of such a paper should account for its provisional character. 
IZA Discussion Paper No. 293

May 2001

\section{ABSTRACT \\ Gender, Comparative Advantage and Labor Market Activity in Immigrant Families *}

The family investment hypothesis predicts that credit-constrained immigrant families adopt a household strategy for financing post-migration human capital investment in which the partner with labor market comparative advantage engages in investment activities and the other partner undertakes labor market activities which finance current consumption. We assess this hypothesis by focusing on two issues: first, the extent to which the specialization in the investing versus financing role is based on comparative advantage versus gender, and second, the extent to which credit constraints offer a potential explanation for observed behavior. Using a unique new Australian data set we find that comparative advantage and gender can be separately identified in migrating families. We find some support for the family investment hypothesis among traditional families (where labor market comparative advantage resides with the male partner) but not among nontraditional families.

JEL Classification: J61, J22, D10

Keywords: Family investment hypothesis, immigrant families, comparative advantage

Deborah Cobb-Clark

Economics Program

Research School of Social Sciences

$\mathrm{H}$ C Coombs Bld.

The Australian National University

Canberra ACT 0200

Australia

Tel.: +61261253267

Fax: +6126257 1893

Email: dcclark@coombs.anu.edu.au

\footnotetext{
* We thank Chris Worswick, Vincent Hildebrand and Yuri Ostrovsky for helpful discussions. The usual caveat applies. The second author thanks the Social Science and Humanities Research Council of Canada (SSHRC) for financial support.
} 
Previous researchers have hypothesized that credit-constrained immigrant families wishing to make post-migration human capital investments must finance that investment themselves (Long, 1980; Beach and Worswick, 1993; Duleep and Sanders 1993; Worswick, 1996; Baker and Benjamin, 1997). This results in specialization among immigrant family members with one partner investing in host country-specific human capital and the other partner undertaking those labor market activities that facilitate the financing of current consumption. Specifically, secondary workers in immigrant families are expected to be more likely to work, to work longer hours, and to forego their own investment in human capital by initially taking better paying, but dead-end, jobs.

Researchers attempting to evaluate the family investment hypothesis have struggled with important data limitations. First, decisions about which partner will invest and which partner will finance are in principle based on each person's comparative advantage yet it is typically not possible to identify comparative advantage separately from gender. Second, while family units at the time of data collection are identified, family units at the time of migration are completely unknown rasing the possibility that the observed assimilation profiles are the result of selectivity into marriage rather than immigrant settlement. ${ }^{1}$

The Longitudinal Survey of Immigrants to Australia (LSIA) is a new data set which allows us to investigate and overcome these limitations. It contains detailed data for a recent

${ }^{1}$ Researchers often do not know which individuals were married at the time of migration let alone whether they were married to their current spouse. Because this is likely to be a smaller problem for recent rather than established immigrants, there exists the possibility that household formation plays a role in generating observed earnings-age profiles. 
cohort of migrating households including principal applicant status and detailed visa category. A substantial portion of immigrants to Australia are admitted on the basis of a "points test" in which points are awarded for labor market skills. So long as couples in this skilled migrant category designate the individual most likely to satisfy the test as their principal applicant, ${ }^{2}$ data on principal applicant status allows us to separately identify both labor market comparative advantage and gender. Given suitably detailed data, this empirical strategy is feasible in countries, such as Australia and Canada, where skill- based migrants comprise a significant fraction of the immigrant inflow. It is not feasible with data from countries ( notably the United States) where skill-based immigrants represent a small fraction of total immigration. ${ }^{3}$ Our goals in this paper are to examine the distribution of comparative advantage within couples who migrate to Australia together, and then to re-examine the family investment hypothesis by focusing on comparative advantage rather than gender, and by limiting our analysis to immigrant couples who migrated together.

${ }^{2}$ Once an principal applicant applies for and is granted a visa, dependent family members are automatically granted visas as well.

${ }^{3}$ In 1994, 15.4 percent of new immigrants to the United States were skill-based while 31.5 percent entered as immediate relatives of U.S. citizens and an additional 26.5 percent entered through the numerically-limited family categories. In 1995 in Canada, 50.5 percent of new entrants were skill-based and 38.0 percent were family-based. In Australia 32.2 percent of immigrants were admitted in 1994-1995 on the basis of labor market skills, while 33.3 percent were admitted on the basis of family relationships (Cobb-Clark, et al, 2001: Table 1.) 
Our results indicate that more than 16 percent of skill-based couple-households migrating to Australia are "nontraditional" in the sense that it is the female partner who is the principal applicant. The probability that the female partner is the principal applicant has a strong positive correlation with her education and work experience, and a negative correlation with the male partner's work experience and education. Thus, principal applicant status does appear to be related to those characteristics determining comparative advantage in the labor market. Perhaps surprisingly, the fraction of nontraditional families does not appear to vary substantially across region of origin. This is helpful for tests of the family investment hypothesis because it means that, conditional on gender, variation in comparative advantage is not collinear with region of origin (and hence possibly culture).

With this information in hand we implement tests of the family investment hypothesis that follow Baker and Benjamin (1997) in comparing the secondary worker in an immigrant couple to immigrant secondary workers married to non-immigrant spouses. Following that, we carefully consider the role of gender and comparative advantage in our sample of immigrant families. While we find some support for the family investment hypothesis among traditional households, nontraditional households appear to behave quite differently.

In the following section of the paper, the existing literature on the family investment hypothesis is reviewed. Section 2 presents an overview of the LSIA data and a exploration of the relationship between gender, principal applicant status and labor market comparative advantage in that data. Our tests of the family investment hypothesis follow in Section 3. The final section of the paper discusses some general conclusions and provides suggestions for future research. 


\section{The Family Investment Hypothesis}

Early immigration research focused on the relationship between relative immigrant-native earnings on the one hand and year of arrival (cohort effects) and the number of years since migration (typically called assimilation) on the other. ${ }^{4}$ Male immigrants were found to have lower earnings immediately after arrival, but relatively high earnings growth over time. ${ }^{5}$ These patterns were thought to be explained by the difficulties in completely transferring human capital across countries and the resulting need to accumulate host country-specific human capital (Chiswick, 1978). Long (1980) was the first to demonstrate that although immigrant women often have higher earnings than native-born women immediately after migration, relative immigrant-native earnings declined as the number of years since migration increased. The contrast between the patterns for women and those for men lead Long to speculate that immigrant wives were working to finance their husbands' investment in U.S.-specific human capital.

Researchers attempting to empirically evaluate the family investment model have generally adopted one of three approaches. The first approach has been to compare the employment behavior and earnings of immigrants who are assumed to be credit constrained with the native born who are not (Long, 1980; Beach and Worswick, 1993; Worswick 1996; 1999). The difficulty with this, however, is that one cannot separate the effects of credit constraints from other the dimensions of the immigrant experience--for example, a lack of skill transferability

${ }^{4} \mathrm{~A}$ more limited number of studies have focused on participation or unemployment.

${ }^{5}$ See Borjas (1985) and LaLonde and Topel (1992) for a discussion of the methodological issues involved in estimating the magnitude of the assimilation effect. 
(Chiswick, 1978), cultural differences in the preferences for work (Reimers, 1985; Antecol, 1999), or the selectivity associated with endogenous migration decisions (Borjas, 1987)--which lead the behavior of immigrants and natives to differ. A second approach has been to compare the labor market outcomes of those immigrant families believed to require human capital investments with immigrant families who do not (MacPherson and Stewart, 1989; Duleep and Sanders, 1993). ${ }^{6}$ Without corresponding data on the variation in the credit constraints faced by immigrant families, however, this approach does not provide a means of assessing the role of credit constraints per se and again the effects of credit constraints may be confounded by regional/cultural variation in preferences for work. ${ }^{7}$

Finally, Baker and Benjamin (1997) use variation in family nativity (i.e., native, immigrant and mixed families) to assess both the need to invest and the presence of credit constraints. ${ }^{8}$ In addition, their analysis extends previous analyses of the family investment

${ }^{6}$ Duleep and Sanders (1993) focus on potential country-of-origin differences in the need for post-migration human capital investment, while MacPherson and Stewart (1989) incorporate information about husbands' post-migration human capital investments directly into a model of immigrant wives' labor force participation decision.

${ }^{7}$ These early empirical tests of the family investment hypothesis have produced somewhat mixed results. While some researchers find evidence in support of the hypothesis (Duleep and Sanders, 1993), others find only limited (MacPherson and Stewart, 1989) or ambiguous support (Worswick, 1996) for the notion that labor market outcomes in immigrant families can be explained by a family investment strategy.

${ }^{8}$ Baker and Benjamin (1997) refer to this as variation in "family type". 
hypothesis in two other important ways: first, by using pseudo-panel techniques to identify wage and hours assimilation ${ }^{9}$ and second, by explicitly considering alternative explanations for the observed wage and hours profiles. They find that employment assimilation among immigrants to Canada cannot be solely explained by underlying wage assimilation because estimated hours/wage elasticities are too small. Variation in outcomes across immigrant families (who are assumed to be credit constrained) and mixed families (who are not) is, however, consistent with the predictions of the family investment hypothesis leading the authors to conclude that "the family investment model has more empirical support than previously thought."

As Baker and Benjamin note, however, cultural differences in the preference for work between immigrants married to immigrants (in immigrant families) and immigrants married to natives (in mixed families) are also potential explanations for the patterns of hours and wage assimilation that they observe. In particular, if having a native-born spouse promotes the adoption of native preferences (or if there is selectivity into intermarriage) then there may be systematic differences in the behavior of mixed and immigrant families which are unrelated to the presence of credit constraints. Their data soundly reject the hypothesis that own assimilation profiles are the same for immigrant husbands and immigrant wives in mixed families, however. Thus, Baker and Benjamin are able to rule out gender-constant variation in preferences across immigrant and mixed families concluding instead that "the heterogeneity in the sample has both a family and gender component." This conclusion is consistent with the inter-ethnic variation in the gender wage gap observed among immigrants to the United States (Antecol, 1999) which

${ }^{9}$ Using cross-sectional rather than longitudinal data leads to well-known methodological problems in identifying earnings assimilation (Borjas, 1985; LaLonde and Topel, 1992). 
provides additional evidence that cultural differences in gender roles within the family may in fact be quite important. Unfortunately, however, Baker and Benjamin's data do not exhibit sufficient variability to allow them to also rule out this type of more complex preference-based explanation of their results.

Despite the fact that the data available to previous researchers has not allowed them to disentangle gender and comparative advantage, there are nevertheless some hints in the results of previous research that the family investment hypothesis cannot be a complete explanation of immigrant household behaviour and assimilation patterns. For example, if the labor supply and human capital investment behavior of immigrant families is driven by credit constraints, we should observe very recent immigrant families acting consistently with the family investment hypothesis. Credit constraints are almost certainly more binding immediately after migration (Worswick, 1999). Yet there is evidence that while the family investment hypothesis holds for more established immigrants, it does not describe the behavior of very recent immigrants (Worswick, 1996; Baker and Benjamin, 1997). ${ }^{10}$

Our objective is build upon Baker and Benjamin's analysis by distinguishing between the family investment hypothesis and variation in preferences as potential explanations of immigrant behavior. One strategy for doing this would be to directly control for those factors--in particular, ethnic origin or age at migration--which might underlay the heterogeneity in preferences about

\footnotetext{
${ }^{10}$ Note Baker and Benjamin find that the sum of the estimated cohort effects for immigrant husbands and wives are negative for the most recent cohort of immigrants (see Baker and Benjamin, 1997:Table 2). Similarly, Worswick (1996) finds that immigrant women do not supply more hours than native-born women in the first few years after migration.
} 
gender roles within the family (Baker and Benjamin, 1997). We adopt an alternative approach, however. In particular, we use detailed information about the immigration process itself to separately identify both comparative advantage and gender. This additional dimension of variability in our data provides us with a direct test of the relative importance of the family investment hypothesis--which is based on comparative advantage--as opposed to gender-based heterogeneity in preferences as explanations of immigrant behavior. In addition, like Baker and Benjamin (1997) we also exploit variation in family types to assess whether immigrant behavior is consistent with the presence of credit constraints.

\section{Gender and Comparative Advantage in the LSIA}

The Longitudinal Survey of Immigrants to Australia (LSIA) offers us a unique opportunity to re-examine the role of the family in immigrants' early labor market experiences. The LSIA collected a considerable amount of demographic, human capital, and labor market information for a cohort of principal applicants and their spouses. Spanning the first three and a half years of the settlement process, the three waves of data present the opportunity to follow a cohort of recent immigrants to Australia as they enter the labor market and begin looking for work. ${ }^{11}$ As the LSIA data provide no information about native families and only limited information about native-born partners in mixed families it will not be possible to make statements about how immigrant status in and of itself matters. Still, our data for mixed and

${ }^{11}$ Throughout the analysis our estimation samples are restricted to couples in which both partners were separately interviewed (more than 95 percent of eligible cases) and between the ages of 19 and 60. 
immigrant households provide a direct test of the family investment hypothesis. ${ }^{12}$

The LSIA sample generalizes to principal applicants aged 15 and older who arrived in Australia between September 1993 and August 1995. Along with interviewing principal applicants, complete information was also collected for migrating-unit spouses and limited information was collected for other members of the household. See Williams, et al. (1997) and Cobb-Clark, et al. (2001) for more details.

Unlike earlier studies of the family investment hypothesis, our "immigrant" sample is restricted to couples in which the principal applicant and his or her partner is also an immigrant migrating at the same time. This reduces the extent to which our results may be confounded by assortative mating after immigration. ${ }^{13}$

Although conceptually comparative advantage is not synonymous with gender, previous researchers have not had specific information about comparative advantage and have instead proxied comparative advantage with gender in the belief that men are more likely to have the comparative advantage in the labor market while women are more likely to be secondary workers

${ }^{12}$ See Beach and Worswick (1993) for a discussion of the importance of linked husband/wife panel data in directly testing the family investment hypothesis.

${ }^{13}$ Not surprisingly, our data suggest that household formation and dissolution are important demographic phenomena within the immigrant population. Three and a half years after migration, more than 20 percent of principal applicants living with spouses who were not part of the migrating unit had formed new these relationships since migration. Approximately two percent of couples migrating together had split up over the first three years of the settlement process. 
(Long, 1980; MacPherson and Stewart, 1989; Duleep and Sanders, 1993; Beach and Worswick, 1993; Worswick 1996; 1999; Baker and Benjamin, 1997). Apart from the fact that gender is only an imperfect proxy for comparative advantage, this assumption makes it impossible to disentangle explanations for immigrant behavior which are based on comparative advantage (i.e., the family investment hypothesis) from those based on gender (i.e., heterogeneity in preferences). LSIA data, however, separately identify principal applicants and their spouses allowing us to identify comparative advantage by determining which member of the couple met the selection criteria and was granted the visa.

Within each couple we might reasonably expect the principal applicant to have the comparative labor market advantage for three reasons: first, our sample consists of only of immigrants selected on the basis of their labor market skills ${ }^{14}$, second, the points test used to select skilled immigrants closely corresponds to our notion of comparative advantage ${ }^{15}$, and third,

${ }^{14}$ Specifically, we selected Concessional Family, Independent, and Employer Nomination Scheme (ENS) immigrants. The Concessional Family program selects immigrants on the basis of both family connections and labor market skills, while Independent migrants are those without family relationships who are admitted solely on the basis of skills. ENS migrants are admitted as the result of pre-arranged offers of employment from Australian employers. Others who were selected as a result of humanitarian concerns, close family relationships, or for their intention to establish a business in Australia have been dropped from the sample. Information about visa status comes from Department of Immigration and Multicultural Affairs administrative records not self-reports.

${ }^{15}$ The principal applicants in migrating units in both Concessional Family and Independent 
it is reasonable to assume that couples maximize the probability of successfully obtaining a visa by designating the partner with the strongest case as the principal applicant.

We begin by investigating the relationship between principal applicant status, gender, and productivity-related characteristics. The first row of Table 1 demonstrates that the principal applicant in couples gaining admission to Australia in the skill-based category is not always male; more than 16 percent of the time the principal applicant is the female partner.

Furthermore, the data do seem to support the proposition that principal applicant status is related to ones comparative advantage in the labor market. The probability that the wife is the principal applicant has a strong and statistically significant positive correlation with the wife's education and work experience, and a strong negative correlation with the husband's work experience and education (particularly the latter). Interestingly, the presence of children in the household does not have a statistically significant effect on the probability that the female partner is the principal applicant.

\section{[Table 1 about here]}

The final row of Table 1 summarizes the incidence of female principal applicants by region of origin. Perhaps surprisingly, the fraction of nontraditional families does not appear to vary substantially across region of origin and the differences are not statistically significant. This

immigrant classes are subject to a points test. Although the exact test differs in the two programs, applicants are awarded points on the basis of age, educational qualifications, English language ability, occupation, and previous work experience. 
is helpful for tests of the family investment hypothesis because it means that, conditional on gender, variation in comparative advantage is not collinear with region of origin (and hence possibly with culturally based preferences for work or particular gender roles).

In the next section we implement tests of the family investment hypothesis which use principal applicant status rather than gender as a proxy for comparative advantage, and which can therefore separately identify the effects of gender and comparative advantage on the labor market behavior of immigrant households.

\section{Testing the Family Investment Hypothesis}

In principle, household decisions about the division of labor within the household are made on the basis of each individual's comparative advantage so that immigrants with the comparative advantage in labor market activities are expected to devote more resources to human capital investments such as formal education, job search, or job shopping immediately after migration, while their partners are expected to take on the role of financing that investment.

Thus, the family investment hypothesis predicts that relative to native-born couples who are not credit constrained, principal applicants in immigrant families will have relatively high rates of school enrollment and spend more time searching for and shopping among jobs resulting in lower employment and lower labor market participation. Secondary workers in immigrant families, on the other hand, have the comparative advantage in financing their partner's investment and are expected to have higher labor market participation and employment rates along with a lower probability of being enrolled in school. ${ }^{16}$

\footnotetext{
${ }^{16}$ In addition, the family investment hypothesis makes a number of other predictions about
} 


\section{Immigrant Spouses: The Role of Credit Constraints}

In Table 2 we follow the empirical strategy of Baker and Benjamin (1997) in comparing immigrant couples with mixed immigrant/resident couples in order to assess the importance of credit constraints themselves. ${ }^{17}$ Our sample of "mixed" couples consists of immigrants migrating as "spouses" or "fiancees" who are married to (or living as if married to) native-born Australians or to immigrants residing in Australia for more than eight years. Mixed couples are expected to differ from couples that recently migrated together in two ways: first, they are less likely to be making human capital investments, and second, they are less likely to be credit constrained. Given this, the family investment hypothesis suggests that the behavior of immigrant spouses (i.e., secondary workers) in mixed couples will differ from that of spouses (also secondary workers) in immigrant couples even though given our sample definitions both are themselves foreign born. Spouses in immigrant couples are expected to be more likely to

job turnover, tenure, and wage growth. Predictions about labor supply--in particular, labor market participation or hours of work--are not clear, but rather depend on the nature of the investment. If human capital investment takes place primarily off the job then we would expect participation and hours to be relatively low for principal applicants and relatively high for their spouses. Alternatively, if human capital investment takes place primarily on the job, then we would expect principal applicants to work relatively more, while their spouses worked relatively less.

${ }^{17}$ While Baker and Benjamin ( 1997) focused on hours assimilation over time, our short panel does not allow us to consider patterns of hours (or wage) assimilation. Therefore, our focus will be on testing the family investment hypothesis through direct measures of human capital investment shortly after migration. 
finance their immigrant partners' post-migration human capital investment than spouses in mixed couples and are therefore expected to be less likely to invest in job search (either on- or off-thejob) and formal education, but have higher employment and participation rates. Alternatively, if the behavior of foreign-born spouses is driven by heterogeneity in preferences about the appropriate division of labor between men and women rather than variation in credit constraints across mixed and immigrant families we would expect to see little difference in outcomes across mixed and immigrant families after we hold constant the gender of the principal applicant.

The estimates reported in Table 2 are from linear probability models estimated using our sample of spouses all of whom are immigrants. The coefficients can be interpreted as the difference between spouses in immigrant and mixed households (in percentage points) controlling for observable characteristics. The observable characteristics we control for are: age and education of the secondary worker, age of their partner, number of children in the household, number of adults in the household, region of origin, and state of residence in Australia. We use White's heteroscedasticity consistent variance-covariance estimate, and report t-statistics in square parenthesis.

\section{[Table 2 about here]}

Consider first traditional families (column 1). Controlling for observable characteristics, foreign-born women who are secondary workers married to immigrants (and hence likely to be credit constrained) are more likely to be participating in the labor market at the first interview (about six months after migration) than are foreign-born women who are secondary workers 
married to Australian residents (and hence less likely to be credit constrained). By the third interview, some three and a half years after migration, secondary workers in immigrant households are significantly more likely to be participating and employed in the Australian labor market. These results for traditional families are consistent with the family investment model.

At the same time, we also find that foreign-born women who are secondary workers are more likely to be enrolled in formal education if their husbands are immigrants (and credit constrained) than if their husbands are Australian residents who are less likely to be credit constrained. This is inconsistent with the family investment hypothesis which suggests that credit constraints lead secondary workers to not only work more but also to forgo investment in their own human capital.

When we examine nontraditional families (column 2), we find a pattern which is completely at odds with the predictions of the family investment hypothesis. Controlling for observable characteristics, foreign-born men who are secondary workers married to immigrant women are less likely to participate in the labor market, less likely to be employed and more likely to be students investing in their own human capital than are foreign-born men who are secondary workers married to Australian residents.

Thus, we find mixed evidence on the family investment hypothesis among traditional families while the evidence for nontraditional families is completely at odds with the family investment hypothesis. Note that in these comparisons we are comparing immigrant women to immigrant women and immigrant men to immigrant men so that the comparisons are not confounded by a gender effect nor are they driven by nativity. 


\section{Immigrant Families: Gender and Comparative Advantage}

In the previous section we considered only the behavior of secondary workers in immigrant and mixed families as a means of isolating the effects of credit constraints. In this section, our focus is on both principal applicants and secondary workers in immigrant households. This allows us to estimate models of behavior that simultaneously allow for the effects of gender and comparative advantage (as measured by principal applicant/secondary worker status). Our model controls for the effects of being female, a spouse, and in a traditional family (an interaction of the previous two) on behavior at the first interview as well as in the change in behavior between the first and third interviews (over the first three and a half years after arrival). As in Table 2 the coefficients reported in Table 3 are from linear probability models, the standard errors were calculated using White's heteroscedasticity consistent variancecovariance estimate and the numbers presented in square parenthesis are t-statistics. The set of additional controls is the same as in Table 2 .

\section{[Table 3 about here]}

Because we are comparing men with women and primary workers with secondary workers within immigrant families (and not across family types), it is not clear that the family investment hypothesis makes predictions about the levels of labor market and human capital investment activity. For example, Table 3 indicates that among immigrant families, shortly after migration, conditional on gender, secondary workers are considerably less likely than principal applicants to be employed or participating in the labor market. However, this is not necessarily 
inconsistent with the family investment hypothesis, which says that secondary workers work a lot initially to finance consumption, while principal applicants invest and then see earnings growth. It could be that principal applicants consistently work more than their partners. If the family investment hypothesis holds, however, the gap should increase over time as principal applicants assimilate into the new labor market and the need for consumption financing by the secondary worker decreases. At the same time, the gap in school enrollment rates are expected to decrease as principal applicants complete their human capital investments.

Indeed, the bottom panel of Table 3 indicates that the hours, employment and participation gaps between principal applicants and secondary workers all grew between the first and third interviews, although none of the changes is statistically significant. The results in Table 3 also indicate that, perhaps unsurprisingly, the gender effects--at least in levels-- are very large indeed, and that there are some significant interaction effects for female spouses. Taken together, these results suggest that the behavior of immigrant households is quite complex and while there is weak evidence to support the family investment hypothesis, there is strong evidence that other factors are also at work.

\section{Discussion}

It is appropriate that immigration research move beyond a simple analysis of individuals to consider entire immigrant households. After all, immigrants migrate and live in households and, furthermore, immigration policy typically results in the selection of households rather than individuals. Research on the economics of immigration is also moving beyond simply measuring assimilation to an examination of the factors that affect assimilation and the mechanisms by 
which immigrants (and immigrant households) assimilate. Nevertheless, researchers pursuing these questions face important obstacles. Many of the factors of interest (age of arrival, intermarriage, region of origin, visa category, gender and comparative advantage) are highly confounded, and disentangling their effects is exceedingly difficult.

One way to make progress is to look for cross-national variation in institutions and policies, and for data which is sufficiently detailed to allow the researcher to exploit such institutional variation. In this paper, we have exploited a feature of Australian immigration policy (the large "points- based" or skill-based" visa category) and detailed new data (the Longitudinal Survey of Immigrants to Australia) to disentangle the roles of gender and labor market comparative advantage in the behavior of immigrant households.

We find that a non-trivial fraction of households migrating to Australia in this skill-based visa category designate the female partner as the principal applicant. An examination of education levels and work experience among these households suggests that principal applicant status does indeed correspond to an economic notion of comparative advantage in the labor market. Thus, in these data, the effects gender and comparative advantage in immigrant households can be separately identified.

The family investment hypothesis posits that credit-constrained immigrant families wishing to make post-migration human capital investments must finance that investment themselves. This results in specialization among immigrant family members with one partner investing in host country-specific human capital and the other partner undertaking those labor market activities that facilitate the financing of current consumption. Specifically, relative to their native-born counterparts secondary workers in immigrant families are expected to be more 
likely to work, to work longer hours, and to forego their own investment in human capital by taking jobs that are initially better paying but which offer little prospect for advancement. We implemented tests of the family investment hypothesis on the LSIA data that follow Baker and Benjamin (1997) in comparing the secondary worker in an immigrant couple to immigrant secondary workers with an non-immigrant spouse. We find some support for the family investment hypothesis among traditional households (where the male partner holds comparative advantage), but not among nontraditional households (where the female partner holds comparative advantage in the labor market).

The support we find among traditional households is perhaps more convincing when the nature of a our sample is considered. In order to separate gender and comparative advantage we focus on households qualifying (via the points test) in the skill-based visa class. Among these households the individual with the greatest number of potential points - and thus labor market comparative advantage - should be (and appears to be) designated as the principal applicant. Thus we can separately identify gender and comparative advantage. Note, however, that since these individuals have enough points to qualify they likely have less need to make human capital investments after arrival and are also less likely to be credit constrained. Thus, in order to identify comparative advantage without reference to gender, we may be limiting our analysis to a sample of immigrants for whom the family investment hypothesis is less relevant. This would bias us towards failing to find evidence for the family investment hypothesis. We, in fact, do find support (even in this sample) for the family investment hypothesis among traditional households, but distinctly different behavior among nontraditional households.

Ultimately, we believe that our results suggest two things. First, that the behavior of 
immigrant households as they assimilate into new labor markets is richer than standard version of the family investment hypothesis implies. Gender roles, and perhaps cultural variation in preferences for gender roles also appear to play a significant role. Second, our analysis provides an example of how cross-national variation in institutions and immigration policy can shed light on aspects of immigrant behavior. This would seem to us to be a promising avenue for future research. 


\section{REFERENCES}

Antecol, Heather. "An Examination of Cross-Country Differences in the Gender Gap in Labor Force Participation Rates” Labour Economics, July 2000, 7(4), pp. 409-26.

Baker, Michael, and Dwayne Benjamin. “The Role of the Family in Immigrants' Labor Market Activity: An Evaluation of Alternative Explanations." American Economic Review, September 1997, 87(4), pp.705-27.

Beach, Charles M., and Christopher Worswick. "Is There a Double-Negative Effect on the Earnings of Immigrant Women?” Canadian Public Policy, March 1993, 19(1), pp. 36-53.

Borjas, George. "Assimilation, Change in Cohort Quality, and the Earnings of Immigrants." Journal of Labor Economics, October 1985, 3(4), pp.463-89.

Borjas, George. "Self-selection and the Earnings of Immigrants ." American Economic Review, September 1987, 77(4), pp. 531-53.

Burbidge, John B., Lonnie Magee and A. Leslie. Robb. “Alternative Transformations to Handle Extreme Values of the Dependent Variable." Journal of the American Statistical Association, March 1988, 83(401), pp.123-127.

Chiswick, Barry R. "The Effect of Americanization on the Earnings of Foreign-Born Men." Journal of Political Economy, October 1978, 86(5), pp.897-921.

Cobb-Clark, Deborah A., Marie D. Connolly and Christopher Worswick. "The Job Search and Education Investments of Immigrant Families”. The Australian National University, Working paper, 2001.

Duleep, Harriet Orcutt, and Seth Sanders. "The Decision to Work by Married Immigrant Women.” Industrial and Labor Relations Review, July 1993, 46(4), pp.67-80. 
Lalonde, Robert J., and Topel, Robert H. "The Assimilation of Immigrants in the U.S. Labor Market," in George J. Borjas and Richard B. Freeman, eds., Immigration and the workforce. Chicago: University of Chicago Press, 1992, pp. 67-92.

Long, James, E. "The Effect of Americanization on Earnings: Some Evidence for Women." Journal of Political Economy, June 1990, 88(3), pp. 620-29.

MacPherson, David A. and James A. Stewart. "The Labor Force Participation and Earnings Profiles of Married Female Immigrants." Quarterly Review of Economics and Business, Autumn 1989, 29(3), pp.57-72.

Reimers, Cordelia W. “Cultural Differences in Labor Force Participation among Married Women.” American Economic Review, May 1985, 75(2), pp. 251-55.

Williams, Lynne S., Clive Brooks and Jill Murphy. "The Initial Labour Market Outcomes of Immigrants.” Australian Bulletin of Labour, September 1997, 23(3), pp. 193-213.

Worswick, Christopher. "Immigrant Families in the Canadian labor Market." Canadian Public Policy, December 1996, 22(4), pp.378-396.

Worswick, Christopher. "Credit constraints and the labor supply of immigrant families in Canada.” Canadian Journal of Economics, February 1999, 32(1), pp. 152-170. 


\begin{tabular}{|c|c|}
\hline $\begin{array}{ll}\text { TABLE 1: } & \text { Incidence of "Nontraditional" Hous } \\
& \text { (Percent of Immigrating Couples w }\end{array}$ & Principal Applicant ) \\
\hline Overall & 16.4 \\
\hline $\begin{array}{l}\text { Female's Education } \\
\text { Less than High School } \\
\text { High School } \\
\text { University } \\
\text { Trade } \\
\quad \text { Pearson } \chi_{3}^{2}(\text { p-Value })\end{array}$ & $\begin{array}{l}2.0 \\
1.9 \\
26.4 \\
16.9\end{array}$ \\
\hline $\begin{array}{l}\text { Female Worked in } 12 \text { Months Prior to Migration } \\
\text { No } \\
\text { Yes } \\
\left.\quad \text { Pearson } \chi^{2}{ }_{1} \text { (p-Value }\right) \\
\end{array}$ & $\begin{array}{c}3.5 \\
22.0\end{array}$ \\
\hline $\begin{array}{l}\text { Male's Education } \\
\text { Less than High School } \\
\text { High School } \\
\text { University } \\
\text { Trade } \quad \text { Pearson } \chi_{3}^{2}(\mathrm{p} \text {-Value })\end{array}$ & $\begin{array}{l}27.2 \\
54.0 \\
17.1 \\
10.6\end{array}$ \\
\hline $\begin{array}{l}\text { Male Worked in } 12 \text { Months Prior to Migration } \\
\text { No } \\
\left.\text { Yes } \quad \text { Pearson } \chi_{1}^{2}{ }_{1} \text { p-Value }\right)\end{array}$ & $\begin{array}{l}27.1 \\
15.9\end{array}$ \\
\hline $\begin{array}{l}\text { Young Children in Household } \\
\text { No } \\
\text { Yes } \\
\\
\quad \text { Pearson } \chi_{1}^{2}(\mathrm{p}-\text { Value })\end{array}$ & $0.057(0.98)$ \\
\hline $\begin{array}{l}\text { Any Children in Household } \\
\text { No } \\
\text { Yes } \\
\quad \text { Pearson } \chi_{1}^{2}(\mathrm{p} \text {-Value })\end{array}$ & $0.728(0.77)$ \\
\hline $\begin{array}{l}\text { Regions of Origin } \\
\text { United Kingdom } \\
\text { Asia } \\
\text { North West Europe } \\
\text { South East Europe } \\
\text { Other } \quad \text { Pearson } \chi_{4}^{2}(\mathrm{p} \text {-Value })\end{array}$ & $\begin{array}{l}17.0 \\
16.6 \\
13.5 \\
17.2 \\
13.6\end{array}$ \\
\hline
\end{tabular}




\begin{tabular}{|c|c|c|}
\hline \multirow[t]{2}{*}{ TABLE 2: } & \multicolumn{2}{|c|}{$\begin{array}{l}\text { The Role of Credit Constraints in the Behavior of Foreign-Born, Secondary } \\
\text { Workers by Household Type } \\
\text { (Secondary Workers in Immigrant vs. Mixed Households) }\end{array}$} \\
\hline & $\begin{array}{l}\text { Traditional } \\
\text { (Female Secondary Worker) }\end{array}$ & $\begin{array}{c}\text { Nontraditional } \\
\text { (Male Secondary Worker) }\end{array}$ \\
\hline & $\begin{array}{l}\text { Immigrant Effect (versus mixed) } \\
\text { (ie., Credit Constraint Effect) } \\
\text { (Immigrant Woman Married to } \\
\text { Immigrant Male Principal } \\
\text { Applicant) } \\
- \\
\text { (Immigrant Woman Married to } \\
\text { Male Australian) } \\
\text { coefficient [t-stat] }\end{array}$ & $\begin{array}{l}\text { Immigrant Effect (versus mixed) } \\
\text { (ie, Credit Constraint Effect) } \\
\text { (immigrant Man Married to } \\
\text { Immigrant Female Principal } \\
\text { Applicant) } \\
- \\
\text { (Immigrant Man Married to } \\
\text { Female Australian) } \\
\text { coefficient [t-stat] }\end{array}$ \\
\hline \multicolumn{3}{|c|}{ First Interview } \\
\hline $\begin{array}{l}\text { employed } \\
\text { participant } \\
\text { student } \\
\text { (observations) }\end{array}$ & $\begin{array}{l}0.012[0.47] \\
0.068[2.30] \\
0.071[3.26] \\
(1523)\end{array}$ & $\begin{array}{l}-0.110[-1.95] \\
-0.104[-2.22] \\
0.100[2.30] \\
(599)\end{array}$ \\
\hline \multicolumn{3}{|c|}{ Third Interview } \\
\hline $\begin{array}{l}\text { employed } \\
\text { participant } \\
\text { student } \\
\text { (observations) }\end{array}$ & $\begin{array}{l}0.068[1.95] \\
0.084[2.43] \\
0.043[2.60] \\
(1062)\end{array}$ & $\begin{array}{l}-0.128[-2.31] \\
-0.091[-2.12] \\
0.034[1.13] \\
(367)\end{array}$ \\
\hline \multicolumn{3}{|c|}{$\begin{array}{l}\text { Notes: } \\
\text { 1. Linear probability models } \\
\text { 2. Other regressors include: the inverse hyperbolic sine (ihs) of the number of adults and of the } \\
\text { number of children in the household, a dummy for the presence of children aged } 0-5 \text {, months } \\
\text { since migration, state of residence dummies, region of origin dummies, education dummies, } \\
\text { and a quadratic in age for both head and spouse. The ihs is an alternative transformation } \\
\text { which, unlike the logarithm, handles zeros (see Burbidge et al., 1988.) Full regression results } \\
\text { available from the authors. } \\
\text { 3. t-statistics in square parenthesis. White's heteroscedasticity consistent variance-covariance } \\
\text { estimate used throughout. } \\
\text { 4. Individuals who are not employed, but indicate that their principal activity in the reference } \\
\text { period is education are coded as students. }\end{array}$} \\
\hline
\end{tabular}




\begin{tabular}{|c|c|c|c|}
\hline TABLE 3: & \multicolumn{3}{|c|}{$\begin{array}{l}\text { The Role of Comparative Labor Market Advantage Within Immigrant } \\
\text { Families (Principal Applicants vs. Secondary Workers) }\end{array}$} \\
\hline & $\begin{array}{l}\text { Secondary Worker } \\
\text { Effect }\end{array}$ & Female Effect & $\begin{array}{l}\text { Traditional } \\
\text { Household }\end{array}$ \\
\hline \multicolumn{4}{|c|}{$\begin{array}{l}\text { First Interview Cross Section } \\
\text { All First Interview Respondents } \\
2260 \text { observations ( } 1130 \text { households) }\end{array}$} \\
\hline $\begin{array}{l}\text { employed } \\
\text { participant } \\
\text { enrolled } \\
\text { hours }\end{array}$ & $\begin{array}{r}-0.169[-7.35] \\
-0.175[-8.19] \\
0.006[0.43] \\
-8.526[-8.82]\end{array}$ & $\begin{array}{rr}-0.224 & {[-9.69]} \\
-0.231 & {[-11.97]} \\
-0.042 & {[-2.90]} \\
-11.859 & {[-12.15]}\end{array}$ & $\begin{array}{l}-0.043[-1.58] \\
-0.090[-3.35] \\
-0.00[-0.01] \\
-0.849[-0.76]\end{array}$ \\
\hline \multicolumn{4}{|c|}{$\begin{array}{l}\text { First Interview Effects, } \\
\text { Balanced Panel } \\
\text { eholds x Principal Applican }\end{array}$} \\
\hline $\begin{array}{l}\text { employed } \\
\text { participant } \\
\text { enrolled } \\
\text { hours }\end{array}$ & $\begin{array}{l}-0.156[-6.16] \\
-0.163[-7.00] \\
-0.003[-0.20] \\
-8.046[-7.56]\end{array}$ & $\begin{array}{r}-0.230[-9.00] \\
-0.260[-11.09] \\
-0.039[-2.36] \\
-11.815[-10.99]\end{array}$ & $\begin{array}{ll}-0.026 & {[-0.79]} \\
-0.086 & {[-2.62]} \\
-0.000 & {[-0.00]} \\
-0.628 & {[-0.47]}\end{array}$ \\
\hline \multicolumn{4}{|c|}{$\begin{array}{l}\text { Change, First Interview to Third Interview } \\
\text { Balanced Panel } \\
24 \text { households x Principal Applicant and Spouse x } 2 \text { Interviews) }\end{array}$} \\
\hline $\begin{array}{l}\text { employed } \\
\text { participant } \\
\text { enrolled } \\
\text { hours }\end{array}$ & $\begin{array}{ll}0.033 & {[0.97]} \\
0.048 & {[1.60]} \\
0.063 & {[2.14]} \\
1.615 & {[1.22]}\end{array}$ & $\begin{array}{cc}0.003 & {[-0.07]} \\
0.007 & {[0.23]} \\
0.041 & {[1.38]} \\
-1.613 & {[-0.19]}\end{array}$ & $\begin{array}{r}-0.046[-1.19] \\
0.012[0.33] \\
-0.010[-0.27] \\
-1.369[-0.89]\end{array}$ \\
\hline \multicolumn{4}{|c|}{$\begin{array}{l}\text { Notes: } \\
\text { 1. Linear probability models. } \\
\text { 2. White's heteroscedasticity consistent variance-covariance estimate used throughout and . } \\
\text { allowance is made for within household (across principal applicant and spouse and across } \\
\text { interviews) correlations. t-statistics in parentheses. } \\
\text { 3. Other regressors include: the inverse hyperbolic sine (ihs) of the number of adults and of } \\
\text { the number of children in the household, a dummy for the presence of children aged 0-5, } \\
\text { months since migration, state of residence dummies, region of origin dummies, education } \\
\text { dummies, and a quadratic in age for both head and spouse. The ihs is an alternative } \\
\text { transformation which, unlike the logarithm, handles zeros (see Burbidge et al., 1988.) Full } \\
\text { regression results available from the authors. } \\
\text { 4. "Enrolled" indicates individuals who report that they are enrolled in formal education. }\end{array}$} \\
\hline
\end{tabular}




\section{IZA Discussion Papers}

\section{No Author(s)}

211 A. van Soest M. Das

X. Gong

212 X. Gong

A. van Soest

P. Zhang

213 X. Gong

A. van Soest

E. Villagomez

214 X. Gong

A. van Soest

215 J. Ermisch

M. Francesconi

216 F. Büchel

217 J. Hansen

R. Wahlberg

218 C. Dustmann

A. van Soest

219 F. Kramarz

T. Philippon

220 W. A. Cornelius

E. A. Marcelli

221

C. Grund

222 W.P.M. Vijverberg

223 M. Rosholm

M. Svarer

224 J. Schwarze
Titel

Area

Date

A Structural Labour Supply Model with Nonparametric Preferences

5

$11 / 00$

Sexual Bias and Household Consumption: A

5

$11 / 00$

Semiparametric Analysis of Engel Curves in Rural

China

Mobility in the Urban Labor Market: A Panel Data

1

Analysis for Mexico

$11 / 00$

Family Structure and Female Labour Supply in

5

$11 / 00$

Mexico City

The Effect of Parents' Employment on Children's

Educational Attainment

5

$11 / 00$

The Effects of Overeducation on Productivity in

5

$11 / 00$

Germany - The Firms' Viewpoint

Occupational Gender Composition and

5

$11 / 00$

Wages in Sweden

Parametric and Semiparametric Estimation in

1

$11 / 00$

Models with Misclassified Categorical Dependent

Variables

The Impact of Differential Payroll Tax Subsidies

on Minimum Wage Employment

5

$11 / 00$

The Changing Profile of Mexican Migrants to the

United States: New Evidence from California and

1

$12 / 00$

Mexico

Wages as Risk Compensation in Germany

5

$12 / 00$

Betit: A Family That Nests Probit and Logit

$12 / 00$

Wages, Training, and Job Turnover in a Search-

Matching Model

7

$12 / 00$

Using Panel Data on Income Satisfaction to

Estimate the Equivalence Scale Elasticity 
On the Identification of Relative Wage Rigidity when? Portugal 
239 F. Andersson

K. A. Konrad

240

W. Koeniger

241 W. Koeniger

242 G. Faggio

J. Konings

243 E. Brainerd

244 S. M. Fuess, Jr. M. Millea

245 F. Andersson

K. A. Konrad

246 E. Plug W. Vijverberg

247 E. Plug W. Vijverberg

248 P. M. Picard E. Toulemonde

249 B. M. S. van Praag P. Cardoso

250 T. J. Hatton

J. G. Williamson

251 R. Yemtsov

252

R. Yemtsov

253

R. Yemtsov

254 H. Gersbach

A. Schniewind

255 H. Gersbach

A. Schniewind
Human Capital Investment and Globalization in Extortionary States

5

01/01

Labor and Financial Market Interactions: The

5

01/01

Case of Labor Income Risk and Car Insurance in the UK 1969-95

Trade, Labor Market Rigidities, and Government- 2

$01 / 01$ Financed Technological Change

Job Creation, Job Destruction and Employment 4

01/01

Growth in Transition Countries in the 90's

Economic Reform and Mortality in the Former

4

$01 / 01$

Soviet Union: A Study of the Suicide Epidemic in the 1990s

Pay and Productivity in a Corporatist Economy:

5

$01 / 01$

Evidence from Austria

Globalization and Human Capital Formation

5

$01 / 01$

Schooling, Family Background, and Adoption:

5

01/01

Does Family Income Matter?

Schooling, Family Background, and Adoption:

5

$01 / 01$

Is it Nature or is it Nurture?

The Impact of Labor Markets on Emergence and

2

$01 / 01$

Persistence of Regional Asymmetries

"Should I Pay for You or for Myself?"

3

01/01

The Optimal Level and Composition of

Retirement Benefit Systems

Demographic and Economic Pressure on

Emigration out of Africa

01/01

Labor Markets, Inequality and Poverty in Georgia

01/01

Inequality and Income Distribution in Georgia

4

01/01

Living Standards and Economic Vulnerability in Turkey between 1987 and 1994

4

01/01

Learning of General Equilibrium Effects and the

3

02/01 Unemployment Trap

Product Market Reforms and Unemployment in 3

02/01 
256 T. Boeri

H. Brücker

257 T. Boeri

258 M. Rosholm

K. Scott

L. Husted

259 A. Ferrer-i-Carbonell

B. M.S. van Praag

260 P. Cahuc

F. Postel-Vinay

261 M. Lindahl

262 M. Lindahl

263 N. Datta Gupta N. Smith

264 C. Dustmann

265 M. Rosholm

M. Svarer

266 C. Dustmann O. Kirchkamp

267 A. Newell

268 A. Newell B. Reilly

269 H. Buddelmeyer

270 B. Augurzky C. M. Schmidt

271 B. Augurzky C. M. Schmidt
Eastern Enlargement and EU-Labour Markets:

The Times They Are A-Changin':

Home versus School Learning: 
272 C. Belzil

J. Hansen

273 G. Saint-Paul

274 P. J. Pedersen

N. Smith

275 G. S. Epstein

T. Lecker

276 B. Amable

D. Gatti

277 R. Winter-Ebmer

278 T. M. Andersen

279 T. M. Andersen

280

P. Apps

R. Rees

281

G. Saint-Paul

282

J. Albrecht

A. Björklund

S. Vroman

283 M. Hagedorn

A. Kaul

V. Reinthaler

284 H. Rapoport

A. Weiss

285 J. Jerger

C. Pohnke

A. Spermann

286 M. Fertig

C. M. Schmidt
Heterogeneous Returns to Human Capital and

5

Dynamic Self-Selection

Distribution and Growth in an Economy with

5

03/01

Limited Needs

Unemployment Traps: Do Financial Dis-

3

incentives Matter?

Multi-Generation Model of Immigrant Earnings:

1

Theory and Application

The Impact of Product Market Competition on

5

Employment and Wages

Evaluating an Innovative Redundancy-Retraining 6

Project: The Austrian Steel Foundation

Welfare Policies, Labour Taxation and Inter-

2

04/01

national Integration

Product Market Integration, Wage Dispersion and Unemployment

Household Saving and Full Consumption over

7

04/01

the Life Cycle

Information Technology and the Knowledge

Elites

5

04/01

Is There a Glass Ceiling in Sweden?

5

04/01

Welfare Analysis in a Schumpeterian Growth

7

04/01

Model with Capital

The Optimal Size for a Minority

1

04/01

Gut betreut in den Arbeitsmarkt?

5

04/01

Eine mikroökonometrische Evaluation der

Mannheimer Arbeitsvermittlungsagentur

First- and Second-Generation Migrants in Germany -What Do We Know and What Do People Think 
287 P. Guggenberger

A. Kaul

M. Kolmar

288 D. A. Cobb-Clark

289 L. Cameron

D. A. Cobb-Clark

290 D. A. Cobb-Clark

M. D. Connolly

C. Worswick

291 R. T. Riphahn

292 E. Wasmer

293 D. Cobb-Clark

T. F. Crossley
Efficiency Properties of Labor Taxation in a

3

$04 / 01$ Spatial Model of Restricted Labor Mobility

Getting Ahead: The Determinants of and Payoffs 5

$04 / 01$ to Internal Promotion for Young U.S. Men and Women

Old-Age Support in Developing Countries:

3

$04 / 01$

Labor Supply, Intergenerational Transfers and Living Arrangements

The Job Search and Education Investments of 1

04/01 Immigrant Families

Cohort Effects in the Educational Attainment of 1

05/01 Second Generation Immigrants in Germany: An Analysis of Census Data

Between-group Competition in the Labor Market 5

$05 / 01$ and the Rising Returns to Skill: US and France $1964-2000$

Gender, Comparative Advantage and Labor 1

$05 / 01$ 